\title{
Examination of the structure and the phase composition of the alloy Fe30Al5Zr
}

Kejzlar Pavel, Department of Material Science, Faculty of Mechanical Engineering, Technical University of Liberec. Studentská 2, 46117 Liberec 1, Czech Republic. pavel.kejzlar@tul.cz

Kratochvíl Petr, Department of Metal Physics, Faculty of Mathematics and Physics, Charles University.

Ke Karlovu 5, CZ-12116, Prague 2, Czech Republic. kratochvil@met.mff.cuni.cz

Light optical microscope, X-ray diffraction as well as scanning electron microscope equipped with energy-dispersive $\mathrm{X}$-ray analysis system were used for examination of the structure and the phase composition of the Fe3Al-based material alloyed with 5 at. \% of zirconium in the state as cast and after heat treatment. The occurring phases were identified, their volume fraction in the alloy was determined and the effect of the heat treatment on the structure of the investigated material is described and discussed.

Keywords: Intermetallics, Iron aluminides, Fe-Al-Zr, Structure, Phase composition

\section{References}

[1] POPOVIČ, Š. Nové poznatky a inovace v technologiích. In Strojírenská technologie roč. XII., 2007, 4, p. 3-5. ISSN 1211-4162.

[2] LIU, C. T., et al. Ordered intermetallic alloys: an assessment. Intermetallics 5, 1997, p. $579-596$

[3] MCKAMEY, C. G., et al. A review of recent developments of Fe3Al-based alloys. J. Mater. Res. 8, 1991, Vol. 6, p. 1779-1804.

[4] STOLOFF, N. S.; LIU, C.T. Microstructure and properties of materials (Volume 2). Singapore : World Scientific Publishing Co. Pte. Ltd., 2000. Iron aluminides, p. 139 - 176. ISBN 981-02-4180-1.

[5] MORRIS, D.G. Possibilities for high-temperature strengthening in iron aluminides. Intermetallics 6, 1998, p. 753758.

[6] PALM, M. Concepts derived from phase diagram studies for the strengthening of Fe-Al-based alloy. Intermetallics 13, 2005, p. 1286-1295.

[7] STEIN, F., PALM, M., SAUTHOFF, G. Structure and stability of Laves phases. Part I. Critical assessment of factors controlling Laves phase stability. Intermetallics 12, 2004, p. 713-720.

[8] STEIN, F., PALM, M., SAUTHOFF, G. Structure and stability of Laves phases part II - structure type variations in binary and ternary systems. Intermetallics 13, 2005, p. 1056-1074.

[9] SteIn, F., SAUThOFF. G., PALM, M. Phases and Phase Equilibria in the Fe-Al-Zr System. Z. Metallkd. 2004, 95(6), p. 469-485.

[10] RAGHAVAN, V. Al-Fe-Zr (Aluminum-Iron-Zirconium). Journal of Phase Equilibria and Diffusion. 2006, Vol. 27, No. 3, p. 284-287.

[11] RIGAUD, V., et. al. Thermodynamic assessment of the Fe-Al-Zr phase diagram. CALPHAD: Computer Coupling of Phase Diagrams and Thermochemistry 33, 2009, p. 442-449.

[12] WASILKOVSKA, A., et al. Plastic deformation of Fe-Al polycrystals strenghened with Zr-containing Laves phases : I. Microstructure of undeformed materials. Materials Science and Engineering, 2004, A 380, p. 9-19.

[13] WASILKOVSKA, A., et al. Plastic deformation of Fe-Al polycrystals strenghened with Zr-containing Laves phases : II. Mechnical properties. Materials Science and Engineering, 2004, A 381, p. 1-15.

[14] STEIN, F.; PALM, M.; SAUTHOFF, G. Mechanical properties and oxidation behaviour of two-phase iron aluminium alloys with $\mathrm{Zr}(\mathrm{Fe}, \mathrm{Al}) 2$ Laves phase or $\mathrm{Zr}(\mathrm{Fe} . \mathrm{Al}) 12 \tau 1$ phase. Intermetalics 13, 2005, p. 1275-1285.

[15] CIESLAR, M., KARLÍK, M. Carbide formation in Zr-containing Fe3Al-based alloys. Materials Science and Engineering, 2007, p. 289-293. 